\title{
Autogestão, economia solidária e organização coletivista de produção associada: em direção ao rigor conceitual
}

José HeNRIQUE DE FARIA

Universidade federal do Paraná / Programa de Pós-Graduação em Administração, Curitiba, PR - Brasıl

\begin{abstract}
Resumo
O rigor conceitual é um elemento fundamental na atividade científica. O conceito é uma representação abstrata da realidade, permitindo, pelo seu rigor, a identificação de fenômenos iguais ou semelhantes, tanto quanto a distinção entre fenômenos similares ou diferentes. Este ensaio pretende, ao tomar por base o conceito já estabelecido de autogestão, especialmente em sua dimensão social, distingui-lo de experiências de gestão que contêm características autogestionárias, abrigando-as sob o conceito de organizações coletivistas de produção associada (OCPA). Em outras palavras, sob o capitalismo, os empreendimentos chamados de autogestionários não constituem uma autogestão, mas OCPA, as quais têm características autogestionárias e apresentam-se enquanto formas de resistência ou modelos alternativos aos do sistema de capital. A autogestão social ou as OCPA não são uma nova economia nem uma economia solidária. A autogestão tem uma dimensão social e somente pode existir uma autogestão nas unidades produtivas quando o sistema social for autogestionário. Essas organizações com características autogestionárias correspondem à forma de gestão coletivista de trabalho. Sob o capitalismo, algumas organizações podem ter características predominantemente autogestionárias. Estas são conceituadas aqui como OCPA, que, por estarem inseridas na lógica do capital, atuam como unidades no sistema de capital.
\end{abstract}

Palavras-chave: Organizações coletivistas de produção associada. Autogestão social. Economia solidária. Gestão organizacional. Organização do trabalho.

\section{Self-management, solidarity economy and collectivist organizations of joint production: toward a conceptual accuracy}

\begin{abstract}
Conceptual accuracy is a fundamental element in scientific activity. The concept is an abstract representation of reality, allowing to identify the same or similar phenomena, as well as to distinguish different phenomena. This article aims to distinguish the well-established concept of self-management- especially in its social dimension-from management experiences with self-management features and recognized under the concept of Collectivist Organizations of Joint Production- OCPA. In other words, under capitalism, the so-called self-managed enterprises do not constitute self-management. They can be considered as OCPA, which have characteristics of self-managed organizations and present themselves as forms of resistance or alternative models to the system of capital. Social self-management or collectivist organizations formed by producers in association are neither related to a new economy nor to a solidarity economy. Self-management has a social dimension and can only exist in self-managed production units when the social system is self-managed. These organizations with self-management characteristics are related to collectivist management of labor. Under capitalism, some organizations may have, predominantly, self-management characteristics. These organizations are conceptualized here as Collectivist Organizations of Joint Production, and, because they are inserted into the logic of capital, they act as units in the system of capital.
\end{abstract}

Keywords: Collectivist Organizations of Joint Production. Social Self-Management. Solidarity Economy. Organizational Self-Management. Organization of Labor.

\section{Autogestión, economía solidaria y organización colectivista de producción asociada: hacia el rigor conceptual}

\section{Resumen}

El rigor conceptual es un elemento fundamental en la actividad científica. El concepto es una representación abstracta de la realidad, lo que permite, por su rigor, la identificación de fenómenos iguales o similares, tanto como la distinción entre fenómenos similares o diferentes. Este ensayo se propone, al tomar por base el concepto ya establecido de la autogestión, especialmente en su dimensión social, distinguirlo de experiencias de gestión que contienen características autogestionarias, congregadas bajo el concepto de Organización Colectivista de Producción Asociada - OCPA. En otras palabras, bajo el capitalismo, las empresas llamadas autoadministradas, no constituyen una autogestión, sino organizaciones asociadas de producción colectivistas, que tienen características autogestionarias y se presentan como formas de resistencia o modelos alternativos a los del sistema de capital. La autogestión social o las organizaciones colectivistas de productores asociados no son ni una nueva economía y ni una economía solidaria. La autogestión tiene una dimensión social y sólo puede existir una autogestión en las unidades productivas cuando el sistema social es autogestionario. Estas organizaciones con características autogestionarias corresponden a la forma de administración colectivista de trabajo. Bajo el capitalismo, algunas organizaciones pueden tener características predominantemente autogestionarias. Estas son conceptuadas aquí como organizaciones colectivistas de producción asociada que, por estar insertadas en la lógica del capital, actúan como unidades en el sistema de capital.

Palabras clave: Organizaciones colectivistas de producción asociada. Autogestión social. Economía solidaria. Gestión organizacional. Organización del trabajo.

Artigo submetido em 05 dezembro de 2015 e aceito para publicação em 24 de maio de 2017.

DOI: http://dx.doi.org/10.1590/1679-395157778 


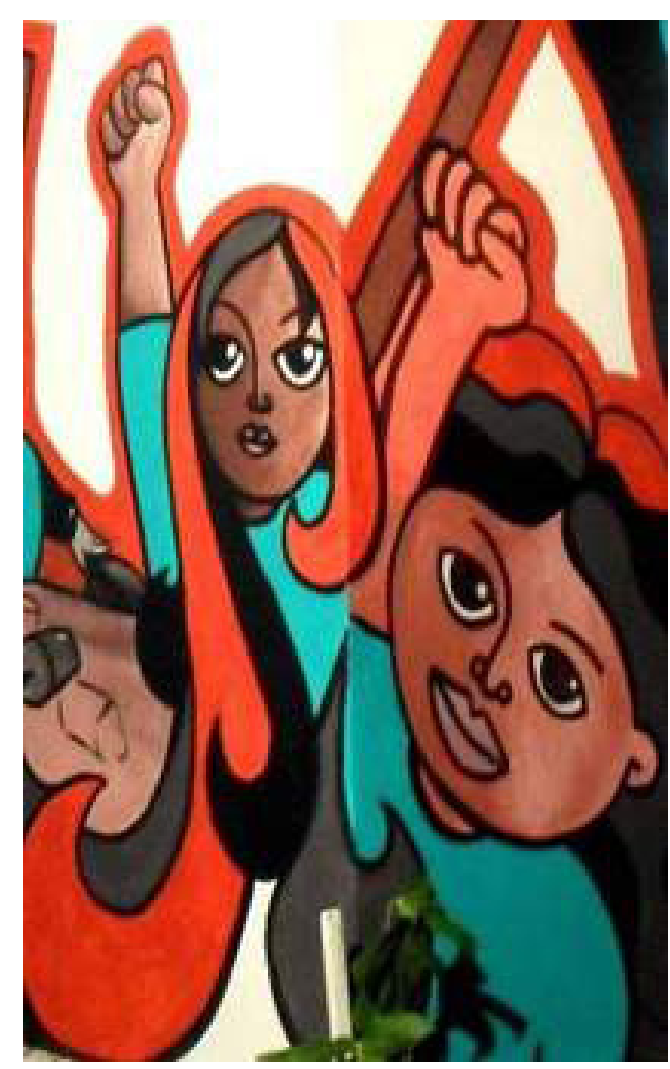

\section{INTRODUÇÃO}

O rigor conceitual é um elemento fundamental na atividade científica. O conceito é uma representação abstrata da realidade, permitindo, pela sua correção e profundidade, a identificação de fenômenos iguais ou semelhantes, tanto quanto a distinção entre fenômenos similares ou diferentes. A definição conceitual de um objeto de estudo depende, obviamente, do método de investigação e da correspondente dimensão epistemológica em que a teoria está abrigada. O conceito de autogestão tem sido exposto com bastante precisão na literatura (GUILLERM e BOURDET, 1976), indicando suas características essenciais ou determinantes. $O$ conceito de autogestão deve ser entendido, neste sentido, não em sua concretude empírica, mas como negação da heterogestão. No entanto, o conceito de autogestão vem sendo aplicado indistintamente para referir processos de gestão que, embora tenham determinadas características autogestionárias, não observam completamente todos os elementos constitutivos essenciais de uma autogestão, ou seja, não se constituem em negação absoluta da heterogestão, em sua oposição. Esse é o caso de estudos que aplicam o conceito de autogestão a empreendimentos de economia solidária (EES) e seus correlatos (fábricas recuperadas, cooperativas de trabalho) (BUSNARDO, 2006; CANÇADO, 2004; CARVALHO, 2012; DICKMANN e DICKMANN, 2015; FARIA, 2005; PEDRINI, 2000; PEDRINI; SOUZA, 2000; TAUILLE e RODRIGUES, 2004; VERARDO, 2003), que, embora observem alguns pressupostos da autogestão, não constituem exatamente empreendimentos autogestionários, o que exige que se retome a discussão das necessárias distinções. Este é o hiato conceitual que este ensaio busca preencher. Em outras palavras, este ensaio pretende, ao tomar por base o conceito já estabelecido de autogestão como negação da heterogestão, especialmente em sua dimensão social (GUILLERM e BOURDET, 1976; FARIA, 1987, 2009), distingui-lo

Fonte da imagem: Disponível em: http://int.search.tb.ask.com/search/AJimage.jhtml?\&n=78394de5\&p2=\%5ECPC\%5Echr999\%5ES18930\%5E\&pg=AJimage \&pn=1\&ptb=86BB6A36-2BE3-4A25-8274-0DBA8E963EB6\&qs=\&searchfor=autogest\%C3\%A3o\&si=\&ss=sub\&st=sb\&tpr=sbt\&imgs=1p\&filter=off\&imgDetail= true. Acesso em 19 jul. 2017. 
de experiências de gestão que contêm determinadas características autogestionárias, abrigando-as sob o conceito de organizações coletivistas de produção associada (OCPA) (FARIA, 2009). Por que essa discussão ainda é necessária?

Desde o final da década de 1960 até os dias atuais tem-se acompanhado uma transformação substancial nas relações de trabalho e nas formas de produção e reprodução do capital. O modelo de organização das atividades produtivas foi alterado para além da busca incessante por mercados globais: ele próprio passou a ser global. No interior das indústrias, observou-se que a implementação de novas tecnologias físicas, bem como as reengenharias, a terceirização e os novos modelos gerenciais, acabaram conduzindo a outra organização do universo das relações sociais (FARIA, 1992). Nas indústrias com produtos de maior valor agregado, intensificou-se a substituição de trabalhadores com a utilização de instrumentos com elevada concentração de capital, resultando em crescentes índices do que se chama de "desemprego tecnológico" nos anos 1980 e 1990 - até nos países mais desenvolvidos. A este fenômeno agregou-se o processo de terceirização de atividades industriais e de serviços com perda gradativa, pelos trabalhadores, de direitos historicamente conquistados.

O processo de trabalho se tornou, também e ao mesmo tempo, mais exigente de qualificação para dar conta das operações com máquinas-ferramentas computadorizadas e baseadas em microeletrônica e cada vez mais precarizado, em decorrência do desalojamento das ocupações e da expulsão dos trabalhadores para a periferia estável ou vulnerável, ou mesmo para as franjas do sistema (FARIA, 2004). Sendo o trabalho elemento central para a constituição do sujeito, condição de existência do homem, independente de todas as formas de sociedade (MARX, 1946), à medida que a essência do trabalho se torna fragilizada, igualmente fragilizada se torna a essência da condição humana. Entretanto, à medida que a força de trabalho assume predominantemente a forma de valor de troca e que o trabalhador está separado dos meios de produção e, consequentemente, dos frutos de seu trabalho, o trabalho criador é substituído pelo trabalho alienado, estranhado. Em outras palavras, durante a vigência histórica do sistema do capital, não tem ocorrido processos de efetivação da emancipação humana, na medida em que sua práxis cotidiana revela o conflito permanente entre capital e trabalho, de onde resulta inevitável alienação (MÉSZÁROS, 2002).

Tendo em vista que as relações de trabalho no sistema do capital se estabelecem de maneira predominantemente heterônoma, todas as alternativas historicamente existentes ou que podem vir a se constituir à heterogestão serão permanentemente desafiadas e, ao mesmo tempo, limitadas pelas estruturas já existentes. Entretanto, esse enfrentamento se faz necessário na medida em que não haverá emancipação sem a subversão das atuais relações de trabalho. A subversão da exploração capitalista do trabalho e sua reversão para uma sociedade do trabalho - em que todos tenham assegurado o direito ao trabalho coletivo e independente - continua a ser a base fundamental de uma sociedade emancipada.

Neste ensaio teórico pretende-se retomar o argumento de que a autogestão plena somente pode ser concebida no plano social, como um modo de produção, entendido este como a forma dominante de organização da sociedade na produção de suas condições materiais de existência. Em outras palavras, sob o modo de produção capitalista, os empreendimentos chamados de autogestionários não constituem uma autogestão, mas OCPA, as quais têm características autogestionárias e apresentam-se enquanto formas de resistência ou modelos alternativos de organização do trabalho vis-à-vis ao do sistema de capital, no plano de unidades produtivas isoladas. O conceito de autogestão, como já mencionado, é uma abstração necessária que se constitui a partir de sua condição de negação ao conceito de heterogestão, ou seja, os elementos constitutivos da autogestão se apresentam como negações aos elementos constitutivos da heterogestão. Nesse sentido, as práticas dessas unidades produtivas ditas autogeridas não são suficientes para que sejam consideradas constitutivas de mudanças na estrutura de reprodução sociometabólica do capital (MÉSZÁROS, 2002). A distinção entre autogestão e empreendimentos com características autogestionárias não é um preciosismo acadêmico, mas uma necessidade crítica que permite avaliar com rigor a potência desses empreendimentos. A sobreposição conceitual exprime uma falsa análise da realidade, criando um obstáculo à reflexão crítica sobre ela. Nesse sentido, é preciso indicar, de saída, que nem a economia solidária é uma autogestão social e nem as OCPA são uma nova economia ou um novo modo de produção. Para tanto, procura-se, aqui, primeiro, expor o conceito de autogestão social e suas características constitutivas; em seguida, procura-se desenvolver uma análise crítica sobre a concepção de economia solidária, que, segundo seus teóricos principais, trata-se de uma nova economia ou um novo modo de produção; posteriormente, colocando em evidência as distinções 
necessárias, apresenta-se o conceito de OCPA como o que define mais corretamente os empreendimentos que, inobstante não sendo autogeridos, têm características autogestionárias.

\section{AUTOGESTÃO SOCIAL}

Enquanto o conselho operário e a cooperativa tentaram ultrapassar a heterogestão, agindo sobre a produção (economia) e a estratégia (política), a autogestão tenta negar a heterogestão e não a ultrapassar, na medida em que pretende ser uma mudança radical (GUILLERM e BOURDET, 1976). A autogestão, como projeto de superação do modo capitalista de produção, destrói a noção de economia atrelada ao lucro, à exploração e à dominação. Rejeita a noção comum de política como função reservada a uma casta de políticos para propor uma economia a partir do que é necessário produzir e uma política enquanto realização em todos os níveis - sem intermediários - de todos os interesses por todos os sujeitos coletivos. A autogestão social deve ser, assim, entendida como modo de produção, ou seja, como um sistema de relações sociais coletivista de produção das condições materiais de existência. A autogestão refere-se a um projeto de superação do sistema de capital, isto é, ao "socialismo democrático".

A autogestão social não pode esgotar-se em uma doutrina, por mais importante que esta venha a ser, porque ela deve, antes de tudo, ser resultado de uma prática, de um projeto político que se opõe não apenas à heterogestão e ao sistema de capital, mas igualmente ao espontaneísmo, à socialdemocracia e ao socialismo burocrático de Estado. Rosanvallon (1979) propõe a existência de 6 "linguagens" distintas sobre autogestão ou 6 concepções diferentes para esse termo. São elas: (i) Linguagem tecnocrática: autogestão é um modelo de gestão descentralizada de empresas que quebra os esquemas de organização centralizada e hierárquica. É a democratização da gestão, a "versão socialista da gestão participativa por objetivos"; (ii) Linguagem libertária: autogestão representa a recusa do Estado e de toda a autoridade. Cultiva a democracia direta contra as formas de representação e delegação; (iii) Linguagem comunista: autogestão designa uma finalidade. É a forma acabada do socialismo, o ponto mais alto da história; (iv) Linguagem conselhista: autogestão é uma sociedade definida pelo poder exercido pelos conselhos operários, é a sociedade dos conselhos que expressam o poder dos produtores, é o poder social dos produtores associados; (v) Linguagem humanista: autogestão é, sobretudo, uma forma de ser, referindo-se mais à "mentalidade" e ao comportamento do que a uma forma de poder. É a valorização do altruísmo e da entrega ao grupo social, é a insistência da transformação da vida cotidiana; e (vi) Linguagem científica: autogestão é a projeção sobre a sociedade das leis de funcionamento do organismo social vivo. A aspiração de uma sociedade em que a funcionalidade das relações sociais se sobrepõe a todas as formas de dominação e hierarquia.

Para Rosanvallon (1979), nenhuma dessas linguagens se apresenta de forma "pura", pois se mesclam em vários "dialetos" e "múltiplas combinações". Entretanto, Rosanvallon (1979) acredita que tais linguagens apenas tratam com um nome novo (autogestão) o que já são teorias sociais antigas (socialismo, democracia direta, tecnocracia, anarquismo, comunismo etc.). A despeito de todas as linguagens e de todas as restrições provocadas por Rosanvallon (1979), é necessário destacar que a autogestão deve ser um projeto concreto que não se constitui de forma paralela ou subsidiária em uma sociedade na qual predomina o sistema de capital. Nesse sentido, nem a linguagem tecnocrática nem a humanista a ela se aplicam. A linguagem científica proposta por Rosanvallon (1979) parece derivar de uma proposição funcional da autogestão, retirando-lhe o caráter de transformação para impregnar-lhe um formato. A linguagem conselhista trata mais de uma república dos conselhos, da organização de pequenas unidades que somente podem tornar-se uma autogestão pela representação de cada esfera e de cada unidade, do que propriamente de uma autogestão social. Sobram, como já se podia deduzir desde o princípio, duas concepções: uma anarquista e outra marxista.

Desse modo, a autogestão plena ou social é: (i) uma nova concepção que não pretende reabilitar o socialismo, mas que objetiva defini-lo em outros termos: socialismo democrático; (ii) definitivamente democrática e realista e que, portanto, atua sobre as dificuldades, os problemas e a complexidade do exercício democrático do poder coletivo; (iii) a apropriação social dos meios de produção e dos meios de poder e de gestão social por parte de toda a sociedade, coletivamente; (iv) ao mesmo tempo, um objetivo dos produtores e uma estratégia de superação revolucionária (qualitativa) das relações 
sociais e de produção; (v) um novo modo de produção e gestão social; (vi) a vinculação entre o desenvolvimento e o modo autônomo de produção, estabelecendo uma relação integrada entre as atividades econômicas e as sociais; (vii) a forma de organização coletiva da sociedade em todas as suas esferas econômicas, sociais, jurídicas e políticas; e (viii) a superação de uma sociedade de classes.

Malgrado exemplos históricos (FARIA, 2009), a autogestão tem sido confundida simplesmente com uma nova forma de administrar empresas ou organizações, sem qualquer relação com a especificidade destas ${ }^{1}$. Já no caso das assim chamadas organizações alternativas, as mesmas (i) podem ser ou não de propriedade comum, (ii) vinculam-se a propostas políticas de democratização da sociedade e igualdade social transformando trabalhadores em proprietários, (iii) podem ser uma forma de gestão de trabalhadores associados como estratégia de recuperação de empresas e sua manutenção no mercado (LIMA, 2007). A autogestão, entretanto, deve ser entendida como uma transformação completa da sociedade em todos os planos (econômico, político e social). Dessa forma, trata-se também (e não apenas) de outra forma de administração, porque a autogestão reconhece a necessidade de um planejamento, de um projeto social, embora não delegue o encargo (e seus privilégios) a uma minoria de especialistas. Sua função é ser uma analisadora no campo histórico e crítico dos sistemas capitalista e da burocracia, no sentido de demonstrar que não existem leis universais para toda a economia, todos os regimes políticos e toda a administração que possam depender, por conseguinte, da ciência dos especialistas.

As diversas experiências de controle operário, na União das Repúblicas Socialistas Soviéticas (URSS), na Itália, na Hungria, na Iugoslávia, na Argélia, na Polônia e na França (FARIA, 2009; LINDENFELD e ROTHSCHILD-WHITT, 1982; HORVAT, MARCOVIC e SUPEK, 1975; MANDEL, 1974), deram origem ao debate teórico sobre a autogestão, influenciando as estratégias implementadas pelo movimento internacional dos trabalhadores (PANIAGO, 2012). Essas experiências tratavam, em síntese, de formas de enfrentamento contra a heterogestão, a favor da participação e da democratização das relações de trabalho e não de um movimento contra o capital.

Autogerir não é democratizar a economia capitalista, mas mudar seus fundamentos. Autogerir a economia é determinar quais são os produtos úteis à condição humana e não os que permitirão aumentar ao máximo o lucro dos proprietários, o poder do Estado burocrático centralizado ou do Estado capitalista. A planificação autogerida não consiste apenas em planejar diferentemente, mas em planejar outra coisa (GUILLERM e BOURDET, 1976), de maneira que se trata de outro modo de produção com outras finalidades. A autogestão se inscreve no movimento de ampliação da democracia, por isso não basta que sua existência se limite às unidades produtivas, pois seu alcance é social. A autogestão social não é nem uma mera extensão da democracia representativa formal a todas as esferas da sociedade nem uma democracia ou gestão participativa, tampouco uma correção dos princípios centralizadores da democracia popular (FARIA, 2009).

Jean Dru (1975) sugere que a autogestão, longe de condenar a organização produtiva a uma luta pela sobrevivência, traz em seu bojo a integração total do processo de produção e da vida social, instalando um sistema de coordenação e de regulação mais flexível e eficaz e permitindo, paralelamente, estabelecer o equilíbrio entre o plano e o processo de troca social.

Como alerta Montuclard (1975), a autogestão também tem sido falsamente interpretada ou (i) como uma forma extrema de participação da classe trabalhadora no processo decisório ou (ii) por meio do centralismo democrático que, de acordo com seus defensores, traz (no direito e nos fatos) tudo o que a autogestão contém de válido. Em ambas as interpretações, que não se excluem, está presente o ethos autoritário: a primeira porque suprime o fato de que o trabalhador, nessas condições, não participa amplamente do processo de decisão, mas do ato decisório; a segunda porque implica a formação praticamente inevitável de uma oligarquia organizacional (MICHELS, 1982). Montuclard (1975) argumenta que a autogestão responde a uma realidade social essencialmente dialética e não é senão dialeticamente que se torna possível assumi-la, tanto em teoria como na prática, pois a autogestão não constitui um sistema liberal, mas libertário, de tal forma que cada valor só tenha proporção em oposição ao seu contrário. Em outros termos, a autogestão é a forma de superação das relações capitalistas de produção e não um ideário; é um projeto a ser social e coletivamente construído e não uma realidade sobre a qual se quer imputar uma nova economia.

\footnotetext{
${ }^{1}$ Tome-se, como exemplo, a declaração do Presidente do Conselho Administrativo do Clube Atlético Paranaense (CAP) em um programa esportivo de âmbito nacional, afirmando que a construção da Arena da Baixada, no período 2013-2014, foi realizada sob o sistema da autogestão. O que ele referiu foi o fato desse clube de futebol brasileiro não ter contratado uma empresa para administrar a construção, ou seja, não terceirizou a gestão da obra e não adotou um regime de parceria. Obviamente, não se pode esperar precisão conceitual do senso comum, mas é possível supor que o emprego da expressão "autogestão" ganhou contornos genéricos e inexatos.
} 
Assim, os que postulam a autogestão por meio de um processo dirigido por uma vanguarda deixam de considerar que autogestão designa uma organização mais ampla e que, em todo o caso, está ligada a um projeto democrático. A autogestão deve surgir por meio de práticas políticas de movimentos coletivos que resultem em uma mudança qualitativa em relação à heterogestão. A autogestão é da ordem de contradição, de onde surge, trazendo em si sua própria negação, o que confere uma constante necessidade de mudança, como de resto qualquer forma de gestão social. A autogestão não é uma doutrina formada, um dogma estabelecido, antes, é a negação do autoritarismo, da heterogestão, o que não implica perfeição, mas outra negação, na medida em que é um modo histórico de produção e de gestão.

A autogestão, em resumo, ultrapassa toda e qualquer proposta democratizante no âmbito da gestão participativa, na medida em que não pretende simplesmente criar grupos de trabalho autônomos ou abolir determinados graus de autoridade nas organizações, mas abolir as estruturas autoritárias da sociedade e de suas organizações. Não se trata de uma proposta conciliadora que pressupõe o fim do conflito entre capital e trabalho por meio da panaceia participativa, mas de outra coisa. Trata-se de uma mudança radical e revolucionária (qualitativa) do sistema de capital, com o objetivo de criar outro e superior modo de produção e de gestão social.

A autogestão plena, social, é contemplada e ao mesmo tempo contempla a gestão coletivista de trabalho associado, a qual se concretiza em OCPA. No entanto, a OCPA, ela mesma, não constitui a autogestão e nem se constitui em uma autogestão, pois esta não está dada de antemão em experiências singulares. Suas pré-condições são aquelas de superação do sistema de capital e de todas as suas contradições, mas sua forma e seu conteúdo real somente podem ter materialidade na prática política dos que forem sujeitos de sua construção.

\section{Autogestão e Gestão Coletivista de Produção}

Todas as experiências históricas ligadas à autogestão não foram capazes de reproduzir-se a médio e longo prazo. Devido a esse fracasso, o termo autogestão viveu durante a década de 1970 até a década de 1990 um longo período de ostracismo, quando passou a ser utilizado novamente. Entretanto, seu uso é retomado com um novo significado, ou seja, apesar de historicamente o conceito de autogestão ter surgido para definir um conjunto de relações que conformam determinado modo de organização da sociedade, recentemente tem sido difundido tanto para definir experiências de organização autônoma de trabalhadores no interior do capitalismo quanto para definir a gestão própria e independente de organizações capitalistas. Enquanto a primeira concepção é uma simplificação, a segunda é uma evidente usurpação do conceito original. Nenhuma delas faz jus à autogestão tal como deve ser definida historicamente no processo de desenvolvimento das forças produtivas.

No atual contexto histórico específico, de fato, a concepção de autogestão surge como simples negação em pequena escala de determinado modelo de produção e as ações e relações que a constituem estão fundamentadas nessa tentativa de negação formal. Buscando compreender tal contexto, Greenberg (1986) identifica que as motivações ou os estímulos para que os trabalhadores se auto-organizem têm como finalidade intrínseca buscar soluções para a alienação ou estranhamento do trabalho, para a gestão das unidades produtivas e para a superação do capitalismo.

O processo de produção, como a atividade orientada para produzir valores de uso que satisfaçam as necessidades humanas, pertence, no modo de produção capitalista, ao capital, que os transforma em valor de troca (MARX, 1946). A autogestão nega o processo capitalista e, portanto, não poderia gerar mais valor privadamente apropriado (GUILLERM e BOURDET, 1976; FARIA, 1985; 1987)². Por consequência, não poderia haver qualquer espécie de autogestão em organizações inseridas no sistema de capital, pois tais experiências singulares não implicam e nem pressupõem uma autogestão no âmbito da organização social (autogestão como síntese). Da mesma forma que se tem mostrado desafiador política, social, econômica e historicamente pensar na realização de qualquer modelo que se aproxime de uma autogestão social, torna-se, na mesma medida, desafiador pensar em uma organização que desenvolva um processo autogestionário em meio à sociedade capitalista. As ações e relações por ela estabelecidas não se dão em meio ao espaço vazio, isto é, todo o tempo será necessário estabelecer relações de (inter)dependência - ou mesmo de enfrentamento (autogestão como antítese) - com o mundo capitalista em que se encontra.

\footnotetext{
${ }^{2}$ Bernstein $(1976,1981)$ apresenta proposta semelhante.
} 
A autogestão refere-se ao controle direto pelos produtores sobre os elementos econômicos e político-ideológicos da gestão do trabalho, mas não só. No nível social, somente pode existir a partir da constituição de um modo de produção e, nesse sentido, experiências em unidades produtivas constituem contradições que se operam no capitalismo, indicativos de viabilidade de sua superação, mas ainda muito incipientes para operar qualquer transformação (FARIA, 1987; 2005; 2009). Como experiência que ultrapassa a forma heterogerida da burocracia e do modelo capitalista de produção, a autogestão não se fixa plenamente no sistema do capital, daí porque o que se encontra neste são organizações com características autogeridas (FARIA, 2006), nas quais prevalece a forma de gestão coletivista de trabalho. Pesquisas realizadas por Christoffoli (2000) e Vargas de Faria (2003), por exemplo, mostram que algumas organizações têm características que se aproximam mais de uma autogestão no nível das unidades produtivas e outras que têm apenas algumas dessas características de autogestão.

Christoffoli (2000) encontra em sua pesquisa, como características dessas organizações, além daquelas referentes ao controle sobre os processos de investimento e acumulação, (i) a eleição e demissão de seus dirigentes e representantes; (ii) a definição das formas de punição e recompensa; (iii) a tomada de decisões a respeito do planejamento e execução da produção e sobre a distribuição de renda nas organizações. Vargas de Faria (2003) ainda adiciona que a autogestão na unidade produtiva pode ser analisada a partir das ações e das relações que se constituem no interior das organizações e destas com o conjunto da sociedade, reconhecendo, porém, os limites e as restrições que o modo de produção capitalista impõe para essas unidades.

Dessa forma, considera-se que aquilo que tem sido amplamente difundido sob o nome de organização autogerida deve ser observado com muito mais rigor conceitual.

\section{ECONOMIA SOLIDÁRIA: EQUÍVOCOS TEÓRICO-CONCEITUAIS E HISTÓRICOS}

As discussões sobre economia solidária, enquanto projeto dos trabalhadores em direção a outro modo de produção, estão carregadas de equívocos, ao mesmo tempo históricos e de ordem teórico-conceitual. O que se pode observar é que a leitura da história da luta dos trabalhadores é enviesada por uma concepção teórica confusa e pouco rigorosa, ao mesmo tempo que a questão teórico-conceitual é fragilizada por uma análise histórica fragmentada e superficial. Trata-se de uma desarmonia entre teoria e realidade histórica.

Resumidamente, existem três distintas proposições para a análise dessa questão: (i) a economia solidária é um novo modo de produção que se ergue paralelamente ao modo capitalista de produção como sua oposição; (ii) o cooperativismo é um movimento que se desenvolve no interior do capitalismo, integrando-se a ele com uma forma diferenciada de organização na realização de atividades associadas ou complementares; (iii) as OCPA, as fábricas recuperadas ou as fábricas-cooperativas de trabalhadores são rupturas no interior da forma de produção capitalista, mas não constituem uma nova forma de produção, senão uma contradição da forma de organização tipicamente capitalista de trabalho e produção. Ainda que as três proposições sejam utilizadas na literatura, do ponto de vista marxista, que é aquele em que se diz apoiar a concepção de economia solidária, apenas a terceira proposição é correta, pois indica que a transformação da sociedade decorre de um processo em que a organização coletivista de trabalho não é inteiramente igual à organização capitalista de trabalho, porém, ainda não se trata de uma nova forma.

Utilizando o que considera uma base marxista de análise, Singer (1999; 2002; 2003; 2004) e Singer e Souza (2000), contudo, desconsideram a terceira proposição e concentram-se nas duas primeiras para tratar do tema economia solidária. Portanto, é no centro da desarmonia entre teoria e realidade histórica que se encontra a análise de Paul Singer, pois esse autor utiliza conceitos marxistas de modo divergente das elaborações originais de Karl Marx. Dessa maneira, a concepção de economia solidária padece de dois equívocos fundamentais: aqueles de ordem teórico-conceitual e aqueles de precisão histórica. Com isso, a teoria é reescrita para dar conta de uma realidade recontada, ao mesmo tempo que a história é reelaborada para justificar uma teoria reinterpretada.

Convém começar pela discussão do concreto, ou seja, pela história. Uma análise concreta sobre os EES permite afirmar que, historicamente, eles jamais foram um projeto político dos trabalhadores em direção à sua emancipação (MENEZES, 2007). A forma histórica de organização cooperativista é tanto uma reação defensiva dos trabalhadores diante das condições econômicas e sociais adversas quanto uma proposta que se alojava em um socialismo utópico. Nesse sentido, não é estranho que, 
do ponto de vista oficial, os EES abranjam tanto um conjunto de experiências de oposição e resistência ao modo capitalista de produção, enquanto estratégia defensiva que se desenvolve paralelamente ao modo dominante, quanto as diferentes formas de inserção alternativa no sistema de capital.

A proposição, pelo governo federal, de uma política denominada economia solidária, enquanto mecanismo de consolidação de organizações populares de geração de emprego e renda por meio de grupos comunitários, associações ou cooperativas, coloca em uma mesma posição formas diferenciadas de unidades produtivas. Ainda que se trate de um processo que teve várias denominações, entre as quais se destacam socioeconomia solidária, economia popular e solidária, nova economia social e novo cooperativismo, no Brasil, especialmente com a criação em 2003 da Secretaria Nacional de Economia Solidária (Senaes), institucionalizou-se a expressão "economia solidária". Pode-se encontrar sob esta denominação, por exemplo, empreendimentos nos quais o trabalho é realizado em unidades familiares, envolvendo vários membros da família na produção de mercadorias, tendo como contrapartida a remuneração por peças produzidas, a qual é realizada por um intermediário ou atravessador mercantil para revenda em unidades comerciais capitalistas.

Convém observar que a finalidade da Senaes é "promover o fortalecimento e a divulgação da economia solidária mediante políticas integradas, visando ao desenvolvimento por meio da geração de trabalho e renda com inclusão social”3. Segundo consta no site da Senaes, a economia solidária (i) "implica [a] reversão da lógica capitalista ao se opor à exploração do trabalho e dos recursos naturais, considerando o ser humano na sua integralidade como sujeito e finalidade da atividade econômica"; (ii) "resgata as lutas históricas dos trabalhadores que tiveram origem no início do século XIX, sob a forma de cooperativismo, como uma das formas de resistência contra o avanço avassalador do capitalismo industrial"; e (iii) "no Brasil, ela ressurge no final do Século XX como resposta dos trabalhadores às novas formas de exclusão e exploração no mundo do trabalho". Entretanto, uma análise de EES sugere que não há consenso entre os sujeitos que experienciam tais empreendimentos sobre sua definição e delimitação (TEIXEIRA, 2010).

Para Singer e Souza (2000), os implantes socialistas, como, por exemplo, as cooperativas, são vistos ao longo da história como uma lenta revolução. Exige-se compreendê-los e, para tal, Singer e Souza (2000) propõem separar o conceito de revolução social do de revolução política, a fim de reconceituar o socialismo. Suas teses se apresentam favoráveis à ideia de que é possível construir uma sociedade socialista sem revolução política, partindo da concepção de que a revolução social capitalista na Inglaterra teria começado com a implantação do capitalismo como modo de produção e perdurado até sua consolidação como modo de produção hegemônico.

Essa argumentação é própria do reformismo marxista, denominado "economicismo", que propunha a luta no plano econômico como sendo da alçada dos trabalhadores e a luta no campo político como sendo de competência de profissionais (o atributo da direção política reservado aos dirigentes esclarecidos). Assim, torna-se desnecessária a conquista do poder político do Estado pelos trabalhadores, pois os intelectuais e os tecnocratas vinculados a eles podem ocupar postos estratégicos no aparelho de Estado capitalista, de onde criam as condições institucionais de uma revolução pela ocupação dos terrenos econômicos desprezados pelo grande capital.

Nesse sentido é que, para Singer e Souza (2000), o modo solidário de produção e distribuição, que parece, à primeira vista, um híbrido entre o capitalismo e a pequena produção de mercadorias, é na realidade, uma síntese que supera ambos.

Singer e Souza (2000) consideram que a unidade típica da economia solidária é a cooperativa de produção, cujos princípios organizativos são:

i) Posse coletiva dos meios de produção pelas pessoas que os utilizam para produzir;

ii) Gestão democrática da empresa ou por participação direta (quando o número de cooperadores não é demasiado) ou por representação;

iii) Repartição da receita líquida entre os cooperadores por critérios aprovados após discussões e negociações entre todos; e

iv) Destinação do excedente anual (denominado de "sobras") também por critérios acertados entre todos os cooperadores.

\footnotetext{
${ }^{3}$ Os dados sobre os EES aqui referidos foram obtidos no site do Ministério do Trabalho.
} 
O esforço teórico e empírico de Singer e Souza (2000) centra-se na necessidade de superar as condições sociais atuais e, com isso, revela seu empenho em "reescrever a luta dos trabalhadores pelo socialismo, nos últimos 200 anos, como se ela constituísse uma história do desenvolvimento progressivo da 'economia solidária'” (GERMER, 2007, p. 53-54). Singer e Souza (2000) desconsideram que o fenômeno do cooperativismo constituiu ocupação de fábricas falidas e, nesse sentido, apenas uma consequência imediata das lutas dos trabalhadores contra o desemprego e também como projeto utópico de reforma social proposto por "indivíduos bem-intencionados" - Conde de Saint-Simon, Pierre-Joseph Proudhon, Charles Owen. As reações defensivas dos trabalhadores contra o desemprego e os projetos de socialismo utópico estão longe de ser um "cooperativismo revolucionário" e uma fase inicial da economia solidária enquanto modo de produção, como argumentam Singer e Souza (2000).

Ainda que o cooperativismo seja, historicamente, uma forma de organização do trabalho não tipicamente capitalista, em nenhum momento ele constituiu um projeto real de transformação social dos trabalhadores. Ao contrário, com a consolidação do capitalismo, o cooperativismo foi-se convertendo em obstáculo à luta política dos trabalhadores por sua emancipação. Atualmente, as organizações cooperativas, sejam as da agroindústria, da produção industrial ou dos serviços, ocupam um lugar de destaque no modo capitalista de produção e atuam nos mesmos moldes de uma empresa capitalista típica ${ }^{4}$.

As crises de acumulação que o sistema de capital atravessa ao longo da história trazem à tona propostas "milagrosas" de solução para os trabalhadores desempregados, socialmente excluídos e miseráveis, tendo por objetivo a constituição de certo tipo de socialismo. O novo modo de produção não é, dessa forma, a construção histórica dos trabalhadores em luta contra o capital, mas uma política de cúpula que se apresenta como a última tábua de salvação pela adesão ao sistema de capital na forma de solidariedade em pequenos empreendimentos.

A economia solidária, tal como proposta por Paul Singer, enquanto novo modo de produção, não constitui uma propriedade social dos meios de produção e um planejamento democrático e integrado da economia, mas um conjunto de empreendimentos isolados de trabalhadores associados em núcleos de produção e serviço. Sendo, como afirmam Singer e Souza (2000, p. 13), a "cooperativa de produção" a "unidade típica da economia solidária", é preciso, de fato, separar as cooperativas empresariais das OCPA. As primeiras são unidades capitalistas de produção que se beneficiam economicamente da legislação do cooperativismo no Brasil. Estas surgiram com o próprio capitalismo e estruturaram-se em conformidade com o modo capitalista de produção e circulação de mercadorias e serviços. Tais cooperativas empresariais de produção (com destaque para as agroindustriais e as de serviços, de crédito e de consumo) tomaram a forma de empreendimentos capitalistas.

As segundas, as OCPA, são organizações produtivas sob o controle dos trabalhadores, seja a partir da tomada de empreendimentos falidos, seja como resultado de iniciativas de organização do trabalho como decorrência de uma ação política. Ao contrário das primeiras, que se tornaram empreendimentos fortalecidos devido à inserção plena no sistema de capital, estas não se desenvolveram da mesma forma. Entre outros motivos, segundo Germer (2007, p. 64-65), devido ao fato de que nelas "os próprios trabalhadores assumem o controle pleno da empresa e da produção, no estágio mais avançado da produção capitalista [tornando] evidente e público que os capitalistas não são indispensáveis para a realização da produção", merecendo a "hostilidade" do sistema de capital.

A não distinção correta dos tipos de cooperativas que foram historicamente constituídas permite a Paul Singer colocar em uma mesma posição os dois tipos básicos. Evidentemente, tal generalização decorre de uma leitura superficial do desenvolvimento histórico desses empreendimentos, amparado por uma teoria pouco rigorosa, ao mesmo tempo que também permite renunciar à elaboração de uma teoria historicamente consistente, abrindo espaço para uma abstração arbitrária.

Trata-se, agora, de verificar como a leitura imprecisa do concreto permitiu a elaboração de uma teoria equivocada. O conceito de economia solidária não é senão uma designação de um conjunto diferenciado e heterogêneo de organizações aparentemente não capitalistas, mas que: (i) ou estão inseridas no sistema de capital como parte dele, inclusive utilizando a lógica de circulação de mercadorias e de capital; (ii) ou estão integradas ao sistema de capital como dependente dele, sobrevivendo em suas franjas e tentando resolver suas contradições mais evidentes: desemprego estrutural, distribuição de renda,

\footnotetext{
4 "O cooperativismo agropecuário tem importante participação na economia brasileira, sendo responsável por quase $50 \%$ do PIB agrícola e envolvendo mais de 1 milhão de pessoas. Dentre todos os ramos de atuação do cooperativismo brasileiro, o agropecuário tem papel de destaque, com 1.597 instituições e 180,1 mil produtores cooperados. Estima-se, ainda, segundo dados do Censo Agropecuário do IBGE (Instituto Brasileiro de Geografia e Estatística), que $48 \%$ de tudo que é produzido no campo brasileiro passa, de alguma forma, por uma cooperativa". Ver: http://www.agricultura.gov.br/assuntos/ cooperativismo-associativismo/cooperativismo-brasil.
} 
desalojamento de ocupações decorrentes de avanços na base tecnológica, apaziguamento de conflitos sociais; (iii) ou, ainda, atuando como atividade complementar ao sistema de capital em áreas que para este são de baixa produtividade e rentabilidade, tais como, coleta de papéis e papelões usados, seleção de lixo para reciclagem em residências e estabelecimentos comerciais, entre outras. Trata-se de uma tentativa de abrigar sob uma mesma denominação todos os tipos de organizações formalmente não capitalistas.

Cooperativas, associações comunitárias de produção, empresas denominadas de autogestionárias ou fábricas recuperadas, redes de produção, comercialização e consumo, grupos informais produtivos de segmentos específicos, clubes de troca etc., são todos considerados EES. A generalização conceitual aqui encontrada, na qual tipos diversos de empreendimentos são agrupados sob uma única denominação, é um aproveitamento de práticas distintas para efeitos de programas de governo e não o estabelecimento de uma teoria com rigor conceitual com base histórica.

De pronto, a economia trata da produção e da troca de mercadorias por equivalentes de valor. Isso significa, objetivamente, que há um necessário confronto de interesses e necessidades que se resolvem de forma não isonômica pela disputa do mercado, ou seja, pela concorrência entre produtores e entre compradores e por uma tensão entre ambos. A solidariedade é um fenômeno social no qual prevalecem interesses comuns e responsabilidades recíprocas, ou seja, um fenômeno que "considera que tanto concorrência como solidariedade estão presentes na natureza e, portanto, poderiam ser entendidos como elementos naturais, presentes em qualquer sociedade" (CARLEIAL, 2008, p. 10). Duas questões emergem aqui: (i) economia e solidariedade são termos e conceitos não complementares; (ii) a ação solidária ou a prática da solidariedade entre trabaIhadores no interior de um empreendimento não é suficiente para se falar em economia solidária.

Concretamente, há uma contradição exposta na dialética desse processo de economia e de solidariedade. São fenômenos historicamente excludentes na prática social. Tanto assim que os EES significam, ao mesmo tempo, tanto a defesa contra a precarização do trabalho e dos direitos dos trabalhadores (divergência de interesses e de necessidades no âmbito das relações sociais e de produção) quanto sua inserção formal no sistema de capital (no mundo da concorrência e do mercado). Em outros termos, trata-se de uma política de inclusão social e econômica dos socialmente suprimidos pelo próprio sistema excludente nos termos deste último. Considerem-se, para ilustrar o argumento, dois fatos: (i) cerca de 50\% dos EES fazem parte do Cadastro Nacional de Pessoas Jurídicas (CNPJ), ou seja, existem como propriedade privada de sócios; (ii) parte significativa de EES possui em seus quadros, além dos sócios, empregados contratados no regime previsto na Consolidação das Leis do Trabalho (CLT), ou seja, praticam o assalariamento. Assalariamento e propriedade privada são elementos centrais do sistema de capital. O reconhecimento e a inclusão dos EES no modo excludente implicam a subordinação aos parâmetros centrais do sistema de capital.

Operando na lógica da abstração arbitrária, Singer (2002, p. 10) considera que

[...] a Economia Solidária é outro modo de produção, cujos princípios básicos são a propriedade associada ou coletiva do capital e o direito à liberdade individual. A aplicação desses princípios une todos os que produzem numa única classe de trabalhadores que são possuidores de capital por igual em cada cooperativa ou sociedade econômica.

A realidade descrita encontra-se apenas na ideia, constituindo uma especulação. Além disso, o conceito tem três fragilidades evidentes:

i) Quanto ao conceito de modo de produção: caso a economia solidária fosse de fato outro modo de produção, a propriedade associada jamais poderia ser sobre o capital, ainda que em partes iguais, já que este é o fundamento do capitalismo e de seu sistema de associação de acionistas-proprietários.

ii) Quanto à garantia de liberdades individuais: trata-se de mera suposição. A liberdade surge exatamente com o advento do liberalismo e do capitalismo, cuja expressão mais consistente encontra-se na Revolução Francesa, com seu lema "Liberdade, Igualdade e Fraternidade". Essas garantias políticas abrigadas no discurso como palavras de ordem nunca foram cumpridas pelo capitalismo, por mais que tenham sido a base de sua promessa na construção de uma economia baseada na trilogia da solidariedade.

iii) Quanto à economia solidária: caso esta seja entendida apenas como forma de organização em cooperativas ou outras sociedades econômicas, a generalização, em um único conceito, de experiências práticas de diferentes conteúdos e resultados não altera a natureza delas e não autoriza a homogeneização no plano conceitual. 
A realidade da economia solidária no Brasil não deixa margem a dúvidas sobre os paradoxos entre o conceito e as práticas. Mesmo estudos que adotam como ponto de partida a proposta conceitual de Paul Singer (ANDRADA, 2005), acabam mostrando que experiências em cooperativas cabem muito mais no conceito de cooperativismo sob o capitalismo. As principais razões para a constituição de EES não são sequer se tornar alternativas ao capitalismo, mas formas de enfrentamento das contradições do sistema de capital sob o capital, ou seja, do desemprego e da não distribuição de renda. Segundo a própria Senaes, a alternativa ao desemprego (obter maior ganho e complementar a renda) representa $74 \%$ dos motivos para a criação de EES, enquanto a concepção do trabalho associado representa apenas $16 \%$. Não se trata, portanto, de nenhuma ruptura com o modo de produção capitalista.

O que pode haver de novo em iniciativas que são conhecidas desde as manufaturas cooperativas fundadas pelos trabalhadores na Inglaterra, em 1790, e que até hoje não impediram o desemprego, a pobreza e a exclusão social? Seria o fato de assumirem "diferentes configurações", com a criação de um "circuito próprio de produção e consumo, alimentando cadeias socioprodutivas autônomas e, em alguns casos, fortemente baseadas em relações não monetarizadas" e o fato de empreenderem "relações sociais mais permanentes com o mercado" envolvendo "diferentes tipos de parcerias com os poderes públicos", como sugerem França Filho e Laville (2004, p. 15)? É exatamente a generalização dessas experiências nas formas de cooperativas de produção e prestação de serviços, bancos populares, clubes de trocas, associações de serviços, cooperativas sociais, sistemas de trocas locais, empresas sociais, cooperativas de interesse público que França Filho e Laville (2004) apontam como uma tendência para o surgimento da economia solidária.

França Filho e Laville (2004) pretendem encontrar uma explicação menos restrita para a economia solidária, sugerindo que esta exige uma concepção diferente da "economia real", que deixaria de ser uma economia de mercado para ser considerada uma "economia plural". Afirmam, também, que a economia solidária vai além do cooperativismo, já que compreendem iniciativas associativas, tais como organizações não governamentais (ONG) e fundações. A concepção de economia plural é um contrassenso, pois a pluralidade de formas de organização do trabalho sob o regime de produção capitalista não é suficiente para se falar em pluralidade de comportamentos econômicos. Tal economia real reinterpretada não deixaria de ser uma economia de mercado, pois essa é a lógica do sistema de capital. Não é a ideia de realidade que altera a própria realidade. Além disso, colocar sob a denominação de economia solidária ONG, fundações, cooperativas e outras formas associativas, na prática equivale a propor uma classificação na qual tudo o que não seja setor público ${ }^{5}$ ou firma capitalista é economia solidária.

Para Singer (1999, 2004) e Singer e Souza (2000), o desenvolvimento da economia solidária é capaz de criar indícios de uma sociedade socialista nos "interstícios" do capitalismo, ou seja, é capaz de instaurar uma revolução social sem uma revolução política. Esse tipo de concepção introduz a ideia de uma

[...] disputa, no interior da classe trabalhadora, entre o caminho das lutas meramente econômicas, concentradas no cooperativismo e autolimitadas pela ampla superioridade competitiva do grande capital, e as lutas na esfera superior da ideologia, da cultura e da política, visando à conquista do poder de Estado (GERMER, 2007, p. 58).

É possível que os EES teçam relações de trabalho alternativas à heterogestão capitalista. Entretanto, poderão ser relações contraditórias no interior do sistema de capital? Não há, nem histórica nem praticamente, como creditar à economia solidária a possibilidade de constituição a partir de si de outro modo de produção. As fábricas recuperadas, as associações de produtores, as cooperativas de trabalho e de produção são administradas segundo o modelo capitalista de gestão, como já exaustivamente mostrado (FARIA, 2009). Mesmo as OCPA, em sua forma de fábricas-cooperativas e com um modelo de administração com características autogestionárias, continuam submetidas à lógica do capital, não obstante tais experiências sejam contradições ao sistema de capital.

Singer (2004), Singer e Souza (2000) e Mance (2002) propõem a organização dos EES de modo que se isolem das relações capitalistas de produção, que produzam e comercializem seus produtos preferencialmente com outros EES de modo a constituir uma cadeia de solidariedade, uma rede de colaboração solidária, certo comércio solidário artificialmente isolado. Essa forma paralela e nunca contraditória de organizar as atividades de produção, distribuição e consumo apenas atesta a inviabilidade

${ }_{5}^{5}$ Nesse caso, fundações de empresas públicas e privadas seriam distintas pela origem da sua criação? Uma fundação de uma grande empresa capitalista seria um EES? 
produtiva e mercadológica de tais iniciativas, além de atuar como um mecanismo protetor isolacionista que condena as organizações à dependência da existência ou não de um mercado protegido. Não é dessa forma que as economias sobrevivem no sistema de capital sequer como atividade complementar. Muito menos é desta forma que tais empreendimentos se constituem em processos revolucionários.

As políticas públicas de economia solidária têm se aproximado perigosamente das políticas assistencialistas. Ao tentar proteger as organizações solidárias dos "efeitos predatórios" do mercado, seja por meio do trabalho de entidades de apoio ou de políticas sociais (Senaes), tais políticas relegam esses empreendimentos a um plano de dependência quase completa. Apesar de buscar construir outras relações de trabalho, acabam criando condições de dependência ainda mais irreversíveis. Tem razão Demo (2002, p. 22) quando afirma:

Em sua práxis histórica, a solidariedade tem servido para imbecilizar e envolver malandramente os pobres, tornando-se procedimento comum de políticas públicas governamentais assistencialistas [...]. O oprimido não sai da opressão se não souber confrontar-se com o opressor [...]. A solidariedade [...] pode representar discurso dos dominantes para acalmar os excluídos. Menos que crítica da realidade atual, pode ser apenas efeito de poder, ao repor o mesmo e velho sentido colonialista de propostas advindas do centro.

A economia solidária, em suas vertentes de economia dos setores populares, é insuficiente para postular uma alternativa integral. À medida que se define em espaços não ocupados, não deixa de ser decorrente da lógica do capitalismo e não há como supor que estaria sendo forjada uma alternativa a este. Para alcançar a emancipação, afirma Demo (2002), é necessário que os trabalhadores deixem a condição de objeto de ajuda para se tornar capacitados a organizar, a partir de si, as oportunidades de vida e suas alternativas. A solidariedade só pode ser proposta correta e historicamente factível se "contar com sujeitos que saibam se emancipar, seja para não recair em outra arapuca do poder, seja para não imaginar resultados definitivos, seja para não perder a autocrítica" (DEMO, 2002, p. 150).

As teorias e as práticas de economia solidária como uma superação do capitalismo não demonstram que, ao optar por constituir EES, os trabalhadores mostrem interesse em se contrapor ao modo capitalista de produção. Isso pode acontecer em algumas OCPA, mas não pelo fato de serem EES, pois precederam essa definição e apenas foram enquadrados nela. Pode-se perguntar se, na maioria dos casos, os trabalhadores se apropriaram do modo de produção capitalista como seu elemento contraditório ou foram incluídos nele? Vivem à sua margem ou vivem do trabalho sem vínculo? Por que parte importante dos EES está, de alguma maneira, vinculada a projetos sociais de apoio à geração de trabalho e renda, seja por meio das incubadoras universitárias, seja pelos sindicatos, grupos religiosos ou outras associações de apoio? Por que os EES não decorrem de iniciativa dos trabalhadores, mas de projetos construídos, organizados, viabilizados ou assessorados por intelectuais universitários, por militantes de partidos, sindicatos e centrais sindicais ou por membros de instituição religiosa?

O que tanto se popularizou como economia solidária nasceu nos muros de universidades, igrejas e outras associações. Nos encontros e seminários sobre economia solidária, parece haver uma persistente tentativa dos grupos oriundos dessas organizações de colocar suas ideias em prática. As características dos EES não são frutos da construção social dos trabalhadores, mas da construção teórica de intelectuais, baseada em equívocos conceituais e históricos. Os trabalhadores fazem cursos de cooperativismo e autogestão promovidos pelas entidades com o propósito de "prepará-los" para a economia solidária, nos quais aprendem os princípios de gestão das condições propostas. Ressalte-se que o apoio financeiro e de acompanhamento técnico-gerencial à viabilização desses EES está condicionado a essa aceitação.

Não é correto afirmar que os trabalhadores optaram por constituir uma organização de economia solidária, quando essa era a única opção disponível. Da mesma forma, não há sustentação pedagógica, tampouco prática, para pressupor que seis horas de curso sobre economia solidária desperte "nos trabalhadores o interesse e a consciência da importância da práxis autogestionária" (SINGER e SOUZA, 2000). A fragilidade financeira da maioria desses trabalhadores evidencia que a opção pelo EES se dá não pelo anseio de construir "relações de trabalho emancipadas" ou um "modo de produção alternativo", mas sim pela necessidade de ter acesso a trabalho e renda.

Muitos dos EES organizam-se em torno de um posto de troca de mercadorias com o sistema de capital, em uma espécie de feira de produtos em que se trocam as mercadorias produzidas nesses empreendimentos por dinheiro, o "equivalente geral" 
a que Marx (1946) se referia. A solução encontrada, na qual os trabalhadores dos EES teriam poder de estabelecimento do valor das mercadorias, esbarra no sistema de capital que determina o que o conjunto dos indivíduos, incluindo naturalmente os compradores das mercadorias dos EES, devem fazer para ter ou alcançar o equivalente para a obtenção dessas mercadorias. A capacidade de viabilização das trocas de mercadorias por dinheiro no mercado capitalista a que os EES recorrem depende do estabelecimento do valor dessas mercadorias pelos seus produtores, mas também da quantidade de força de trabalho que os compradores venderam no sistema de capital para realizar as trocas.

Os resultados obtidos são confirmados pelas experiências relatadas em um texto organizado por Singer e Souza (2000), segundo o qual os EES apenas diminuem as consequências perversas do desemprego capitalista. De fato, quando Singer e Souza (2000) propõem que a economia solidária no Brasil é uma “autogestão como resposta ao desemprego", reconhecem implicitamente, em primeiro lugar, que o programa não é senão uma tentativa de solução de um problema típico das crises do sistema de capital, o desemprego. O relato das experiências que se encontra no texto organizado por Singer e Souza (2000) mostra, com bastante nitidez, que o termo autogestão é mal-empregado, pois em nenhum dos casos se trata de empreendimento autogestionário. Paul Singer chega a chamar a autogestão de um empreendimento que vai além da ideia de uma empresa, pois se assemelha a uma família marcada por laços afetivos além de ser uma organização social de orientação ideológica.

A concepção segundo a qual as experiências de economia solidária seriam uma demonstração da factibilidade e da supremacia da auto-organização dos trabalhadores e, portanto, da viabilidade do socialismo, tendo por base uma teoria marxista, decorre de uma leitura metafísica desse processo. Dessa leitura se depreende que a superação do capitalismo não mais estaria nas contradições do sistema de capital, nas lutas dos trabalhadores, mas em alternativas que se encontram paralelas a ele, porém, vivendo dele e com ele.

A economia solidária não oferece elementos significativos para uma melhor compreensão dos passos para uma transição para além do capital [...]. A economia solidária se aproxima mais de uma política de controle social que mantém os mais pobres envolvidos na busca de sua precária sobrevivência material por meio de cooperativas e (ou) associações, ensaiando práticas de cooperação e sinergias, porém afastados do que interessa sob o capital, o conflito (CARLEIAL, 2008, p. 13-14).

O discurso de que é necessário romper com a gestão capitalista do trabalho, por parte dos ideólogos dos EES, tomando por base uma argumentação "marxista", acaba por esconder a diferença fundamental que há entre os trabalhadores administrarem um empreendimento capitalista e a autogestão de empreendimentos sociais de iniciativa dos trabalhadores.

No primeiro caso, os trabalhadores adquirem, legalmente, o direito ao controle do empreendimento já constituído na forma capitalista, muitas vezes em decorrência de decisões judiciais sobre a empresa falida e com um passivo trabalhista que, para ser liquidado, corresponde à transferência de propriedade privada de um capitalista para um grupo de novos sócios. Toda a organização do processo de produção permanece inalterada. O novo empreendimento, com o tempo, contrata trabalhadores assalariados, reforçando ainda mais sua constituição capitalista. Na gestão, estabelece-se um sistema oligárquico de gestão legitimado por assembleias compostas por trabalhadores que desconhecem, em larga medida, as questões da gestão financeira, de logística, de produção, de relacionamento com o mercado, de compromissos na esfera judicial e tributária e de gestão de pessoal. O domínio das informações afasta cada vez mais os gestores escolhidos do "pessoal do chão da fábrica", do "coletivo". Alie-se a isso a presença dos sindicatos e centrais sindicais que, rigorosamente, em uma autogestão não teriam nenhuma razão de existência, pois não se trataria mais de uma defesa dos interesses dos trabalhadores contra o capital ou contra os "patrões", já que em uma "autogestão" todos são, ao mesmo tempo, trabalhadores e gestores de seu próprio empreendimento.

A economia solidária como equivalente a uma autogestão e a um novo modo de produção, como foi possível demonstrar, constitui um equívoco teórico-conceitual e histórico-social. Ao abarcar vários tipos de experiências e enquadrá-las sob a definição genérica de economia solidária, acaba-se por descaracterizar formas específicas de organização e gestão, dificultando o processo de aprender com suas experiências práticas, pois sobre elas pesam teorias e conceitos infundados e leituras históricas distorcidas. Essa é uma forma equivocada de tratar a realidade, encobrindo as práticas das OCPA que se constituem como contradição do sistema de capital com a dos EES e sua inserção no capitalismo a partir de um discurso desarticulado com a realidade. 
A economia solidária não é um novo modo de produção, como afirmam Singer (2002; 2003), Mance (2002), França Filho e Laville (2004), Gaiger (2004) e outros teóricos. Trata-se de um conjunto de empreendimentos que, em sua maioria, constituem resposta ao desemprego e uma forma alternativa de trabalho e renda. Em outros termos, trata-se de empreendimentos constituídos por sócios trabalhadores no interior do sistema de capital ou paralelo a ele, desenvolvendo atividades complementares às das empresas capitalistas. A forma de gestão e de distribuição dos rendimentos não faz desses empreendimentos uma referência revolucionária. São empreendimentos que se encontram prisioneiros da lógica do capital. Alguns poucos empreendimentos, que Marx denominava fábricas-cooperativas, constituem formas de resistência incipientes, capazes de mostrar que na produção de mercadorias o capitalista é dispensável. Esses não são empreendimentos capitalistas, mas também não constituem algo novo. São elementos de um processo de transformação ainda em curso.

Essas formas de organização coletiva de trabalho, conquanto possam indicar certa autonomia associativa, encontram-se submetidas às relações capitalistas, tanto em termos de propriedade jurídica quanto em termos de inserção no processo de circulação de mercadorias e de capital. Em outros termos, tais formas de organização se encontram plenamente inseridas na ordem sociometabólica do capital (MÉSZÁROS, 2002), servindo inclusive ao seu propósito nos momentos de crise estrutural.

\section{ORGANIZAÇÃO COLETIVISTA DE PRODUÇÃO ASSOCIADA}

Uma vez que se tenha esclarecido o conceito de autogestão como um projeto de um novo modo de produção, ao confrontá-lo com o conceito de economia solidária, autointitulado como "novo modo de produção", percebe-se que os empreendimentos desse tipo de economia não são autogestionários, embora alguns deles contenham algumas características da autogestão. Para diferenciar a autogestão dos EES, exige-se um rigor conceitual que possa permitir colocar alguns dos empreendimentos denominados de economia solidária em sua concreticidade, distinguindo-os da generalidade do conceito de autogestão.

Nesse sentido, o que se denomina genericamente autogestão das unidades produtivas será aqui definido de modo mais rigoroso e preciso como OCPA (FARIA, 2009). Não se trata da organização do trabalho associado, conforme definido por Marx (1977), mas de uma forma particular e singular de organizar coletivamente e de maneira associada a produção de mercadorias que circularão no mercado capitalista. Quando inserida no modo de produção capitalista, a OCPA se estrutura na direção contrária às formas heterogeridas da organização capitalista de trabalho. Dessa forma, tal tipo de organização é elemento de contradição do sistema de capital, porém, em pequena escala. No limite, tais organizações são formas inacabadas de transição para uma autogestão social, enquanto processo de construção histórica. Como se pode observar a partir da exposição anterior, somente em uma autogestão social ou plena, ou seja, em outra ordem sociometabólica, é que as OCPA deixam de ter apenas características autogestionárias (autogestão restrita) para se transformar em unidades produtivas autogeridas. De fato, no sistema de capital, as OCPA têm características autogestionárias (autogestão restrita), mas ainda não se consolidaram como empreendimentos autogestionários plenos, pois, para tanto, demandam inserção em um modo de produção autogestionário ou em uma autogestão social.

A essa forma de estrutura organizacional e da autogestão restrita que lhe corresponde se dá, aqui, o nome de OCPA, pois elas correspondem, no limite, à autogestão no nível das unidades produtivas (FARIA, 2009). Trata-se de uma experiência singular de organização do trabalho em que os trabalhadores se associam para a produção coletiva de mercadorias, na qual não há apropriação privada de excedentes de valor. Assim, as OCPA constituem contradições em pequena escala ou formas inacabadas de transição, por ainda não terem se consolidado nem como uma alternativa de superação, já que se organizam sobre as bases capitalistas primárias ou mesmo pré-capitalistas, em estruturas simples, nem como negação, porque não se colocam em luta contra o sistema de capital, mas em posição de recusa à lógica desse sistema, no qual se encontram paradoxalmente inseridas.

O conceito de OCPA derivado da realidade concreta, já exposto em outra análise (FARIA, 2009), requer que:

i) Refira-se a uma organização de produção e não a uma economia, pois se trata de empreendimento, de unidade produtiva e não de um modo de produção;

ii) Apresente sua característica, ou a finalidade de sua constituição, que é a produção das condições materiais de existência de uma comunidade específica e politicamente localizada; 
iii) Identifique o núcleo em torno do qual se constroem os vínculos sociais comuns;

iv) Indique a forma de gestão, que é uma gestão coletivista de trabalho com característica autogestionárias no nível da unidade de produção.

Uma das categorias fundantes do conceito de OCPA é, portanto, o de autogestão restrita, ou seja, as OCPA possuem características autogestionárias no nível das unidades produtivas. Como já exposto, ocorre que diversos estudos têm tratado de casos singulares ou particulares de empreendimentos que se autodenominam autogeridos, mas que em sua prática não a executam, como se estes representassem o conjunto dos EES. O fato de existirem experiências bem-sucedidas de empreendimentos com características autogestionárias no nível de unidades produtivas singulares não permite a generalização, segundo a qual os EES são eles mesmos autogestionários. Não raro, convém insistir, têm-se denominado autogestão alguns empreendimentos que separam administração e produção e que contratam força de trabalho assalariada no mercado de trabalho. Entretanto, não pode ser um empreendimento autogestionário aquele que:

i) Separa a atividade de gestão da de produção, pois essa é uma prática típica da organização científica do trabalho (taylorista-fordista). Nesse tipo de prática, o associado da produção não é o da gestão e, dependendo dos estatutos, talvez seja apenas um membro da assembleia geral de associados;

ii) Explora a força de trabalho, que pratica o assalariamento, pois essa prática exclui o empregado do direito de gestão, tornando-o um heterogerido e transforma o associado em sócio, como em uma organização produtiva capitalista.

O conceito de autogestão ou de cooperativas autogestionárias que tem sido empregado na literatura atual é vago e impreciso. Do ponto de vista teórico, esse é o mais delicado problema de diversos estudos de caso sobre o tema. Há estudos (CHAVES, 2007) que chamam de empreendimentos autogestionários experiências que não são sequer compatíveis com a concepção mais abstrata de autogestão, pois apresentam elementos como: (i) hierarquia; (ii) distinção de remuneração não pela quantidade de trabalho empregado, mas por lugar e por função no processo; (iii) centralização das decisões; (iv) distribuição de "sobras" e não obediência ao princípio de "a cada um segundo sua contribuição e suas necessidades", entre outros.

O fato da Associação Nacional de Trabalhadores e Empresas de Autogestão (ANTEAG) indicar que é possível a contratação tanto de profissionais para administrar o negócio quanto de mão de obra para atender necessidades de produção sem que esse fato faça com que a organização perca seu indicativo de autogestão, não é autorização para uma conceituação permeável por práticas heterogêneas. Não pode haver, nem conceitual nem praticamente, assalariamento em uma organização que se pretende autogerida. Apesar de tudo, os empreendimentos são denominados autogestionários, ou seja, a realidade é conceituada ou denominada por aquilo que ela não é. Desse modo, a opção por um conceito adequado ao estudo desses empreendimentos deve levar em conta organizações produtivas que (i) não são capitalistas, mas contradições do modo capitalista de produção; (ii) contrapõem-se à lógica da acumulação do capital, mas atuam no interior do sistema de capital; (iii) não são alternativas de geração de emprego e renda, mas formas política e economicamente organizadas de trabalho não capitalista. Com isso, emergem quatro grandes questões:

i) Não se trata da criação de outro modo de produção, mas sim de organizações produtivas que estabelecem, ainda que de forma incipiente e frágil, uma relação de enfrentamento com o modo de produção capitalista, sem superá-lo ou mesmo sem enfrentar sua estrutura de reprodução sociometabólica;

ii) Essas organizações não são capazes de estabelecer nenhum modelo autogestionário de caráter universal, pois, para isso, seria necessária uma autogestão social, ou seja, outra ordem sociometabólica. Por isso, devem ser compreendidas na condição de organizações que apresentam características autogestionárias (FARIA, 2006), tendo consciência de que essas características nunca serão plenas enquanto inseridas no sistema de capital. São OCPA, nas quais se manifestam características autogestionárias no nível da unidade produtiva;

iii) É estritamente necessária, para a manutenção das OCPA, a existência de um vínculo efetivo e que não tenha caráter unicamente econômico, isto é, que seja capaz de unir politicamente os trabalhadores em torno de um projeto social comum;

iv) A constituição de uma OCPA com características autogestionárias deve partir da necessidade, interesse e iniciativa do grupo social. A valorização, ou não, dessas características cabe apenas a esse grupo definir, pois, na medida em que forem impostas ou manipuladas externamente, perdem totalmente o sentido coletivo para o grupo social e perdem a validade como experiência de construção política. 
Tendo em vista tais questões é que emerge o conceito de OCPA. Como já exposto em outros estudos (FARIA, 2006; 2009), OCPA é o empreendimento com características autogestionárias, sob o comando dos produtores diretos, o qual tem responsabilidades ou interesses recíprocos no processo de produção e solidariza-se a partir de um vínculo social comum ou recíproco, restrito ao plano organizacional (ao processo interno da unidade produtiva). É uma forma de organização, pelos produtores, da produção das condições materiais de sua própria existência, a partir de relações de responsabilidade entre trabalhadores unidos por interesses e vínculos sociais comuns, de modo que cada sujeito do grupo social se sinta material e politicamente comprometido com os demais sujeitos da organização. As OCPA supõem uma gestão que garanta isonomia entre seus membros tanto na esfera decisória quanto na da propriedade dos meios de produção.

A OCPA, portanto, estrutura-se sob uma base organizacional que (i) valoriza a participação coletiva de seus membros (produtores) no processo decisório; (ii) enfatiza o controle pelos produtores do processo de produção, a colaboração e a solidariedade quanto aos seus projetos e resultados; (iii) adota procedimentos caracteristicamente autogestionários no nível das unidades produtivas (autogestão parcial ou restrita) ou, o que é a mesma coisa, a gestão coletivista de produção, como sua característica diferencial; (iv) estabelece como princípio a partilha das responsabilidades em todas as instâncias ou fases do processo de produção e a adoção de critérios de remuneração dos produtores segundo sua participação proporcional ao trabalho aplicado na formação/elaboração do produto e/ou de acordo com suas necessidades individuais. O caráter associativo desses empreendimentos não confere qualquer garantia de contraposição às regras operacionais da estrutura capitalista (MÉSZÁROS, 2002).

Em outros termos, o processo de trabalho e sua centralidade para a edificação teórica, bem como sua gestão democrática pelos sujeitos coletivos que caracterizam uma OCPA, devem guiar-se por pelo menos quatro critérios: (i) redistribuição igualitária da riqueza material socialmente produzida, a qual corresponde à dimensão econômica; (ii) reconhecimento social, à qual corresponde a dimensão sociocultural; (iii) representação paritária nas esferas de decisão, à qual corresponde a dimensão jurídica-política; e (iv) realização emocional, à qual corresponde a dimensão psicossocial (FARIA, 2015). Por que esses critérios podem ser úteis para determinar as condições do processo social de trabalho e de produção e sua gestão nos termos de uma OCPA? São úteis por dois motivos: (i) porque esses critérios delimitam o campo empírico ao materializar (a) o sujeito coletivo no plano do grupo social (reconhecimento e realização), bem como (b) as formas de organização e de gestão do processo social de trabalho e da prática política (redistribuição e representação); (ii) porque também delimitam o plano ontológico e teórico daí decorrente.

Assim, esse conceito difere de maneira definitiva do que se convencionou estabelecer como uma equivalência entre autogestão e economia solidária. Trata-se da discussão entre modo de produção (autogestão social), tipo de organização (EES) e forma de produção e gestão (OCPA), isto é, entre a totalidade da economia, as firmas (espécies microeconômicas) e as unidades produtivas específicas. A instauração plena de um modo de produção exige engendrar previamente um novo modo material de produção, que lhe seja próprio e adequado, pois isso é o que lhe faculta dominar o conjunto do processo de produção social e subverter a superestrutura que, contra as necessidades de desenvolvimento, ainda sustentam a ordem social. A alteração profunda do modo de apropriação da natureza é, ao mesmo tempo, requisito e vetor de toda nova formação social (GODELIER, 1981).

Considerando a impossibilidade de tais organizações alternativas constituírem de fato "outra economia" atrelada a um novo modo de produção que não o capitalista, torna-se mais coerente a utilização do conceito de OCPA, pois essas são contradições singulares do sistema de capital. Nesses empreendimentos, o trabalho é o elemento central e a manutenção de cada posto tem prioridade maior que a lucratividade (EID, GALLO e PIMENTEL, 2001). As OCPA são empreendimentos coletivistas de produção, regidos por princípios autogestionários de participação coletiva nas decisões, cooperação isonômica no trabaIho, auto-sustentação restrita à unidade produtiva, desenvolvimento de certa responsabilidade política.

Utilizando práticas ainda que parciais ou restritas de autogestão, as OCPA têm natureza singular, uma vez que modificam o princípio e a finalidade da extração do trabalho excedente. Caracterizam-se por funcionar com base na propriedade coletiva (porém, não social) dos meios de produção no nível da unidade de produção, vedando a apropriação individual desses meios ou sua alienação particular. O controle e a decisão pertencem à coletividade dos trabalhadores, em regime de paridade de direitos e sua gestão está atrelada à comunidade de trabalho que organiza o processo produtivo, operando as estratégias econômicas e decidindo sobre o destino do excedente produzido (GAIGER, 1999). Tal mecanismo pressupõe uma reconciliação 
entre o trabalhador e as forças produtivas que ele detém e utiliza. Não sendo mais um elemento descartável e não estando mais separado do produto do seu trabalho, agora sob seu domínio, o trabalhador recupera as condições necessárias para uma experiência integral de vida no trabalho e ascende a um novo patamar de satisfação e de atendimento a aspirações não apenas materiais ou monetárias.

\section{Autogestão no Nível das Unidades Produtivas e Organização do Trabalho}

Unidades produtivas que possuem características autogestionárias podem ser denominadas de unidades de autogestão restrita ou parcial, pois operam em unidades de produção ou de trabalho coletivo. É parcial porque não se realiza plenamente e não se realiza porque se encontra inserida no sistema de capital, compondo sua ordem sociometabólica. Um dos pressupostos básicos para que as OCPA alcancem seus objetivos sociais de transformação nas relações de trabalho se traduz na presença de um modelo de gestão adequado às características peculiares desses empreendimentos. Bobbio, Matteucci e Pasquino (1986) definem autogestão como um sistema de organização das atividades sociais desenvolvidas mediante a cooperação de várias pessoas (atividades produtivas, serviços, atividade administrativa), em que as decisões relativas à gestão são diretamente tomadas por quantos dela participam, com base na atribuição do poder decisório às coletividades definidas por cada uma das estruturas específicas de atividade. São, portanto, identificáveis duas determinações essenciais do conceito de autogestão restrita ou parcial. A primeira é a superação da distinção entre quem toma as decisões e quem as executa, no que diz respeito ao destino dos papéis em cada atividade coletiva organizada com base na divisão do trabalho. A segunda é a autonomia decisória de cada unidade de atividade, ou seja, a superação da interferência de vontades alheias às coletividades concretas na definição do processo decisório.

A autogestão parcial difere do associativismo cooperativo em seu modelo tradicional, pois enquanto este posiciona a condição do trabalho assalariado na redistribuição paritária da propriedade dos meios de produção entre todos os membros de uma unidade econômica como uma alternativa, a autogestão parcial considera a necessidade de redefinição do papel e do poder dos trabalhadores no processo econômico, apontando como condição de tal processo não a aquisição generalizada do status de proprietário privado, mas sim a supressão de tal status e a conquista igualitária do poder de gestão mediante o direito indivisível do usufruto dos meios "sociais" de produção (BOBBIO, MATTEUCCI e PASQUINO, 1986).

A autogestão coletivista de trabalho no nível da unidade produtiva (restrita) pode ser definida como um modo de gestão que tem por pressuposto básico as relações de igualdade e a valorização do trabalhador, na medida em que rompe o processo de alienação direta do trabalho ao capitalista particular, expande e estimula a difusão do conhecimento sobre o processo de trabalho, além de destruir a estrutura hierarquizada verticalmente, de modo que todos se tornem conscientes de sua responsabilidade para com o sucesso ou insucesso do empreendimento.

\section{A Economia de Mercado}

A concepção de OCPA é marcada por uma polêmica fundamental. Há uma corrente que vislumbra nela uma alternativa para a geração de emprego e renda no capitalismo e outra que considera tal proposta como inviável e utópica. Ambas fazem com que o tema constitua alvo de críticas contundentes. Mesmo entre seus proponentes não há unicidade de discurso. Da parte dos opositores são lançadas críticas chamando a atenção para a natureza contraditória das propostas no campo das OCPA. A mais contundente de todas as contradições existentes reside na seguinte questão: como uma organização desse tipo pode sobreviver ao ambiente altamente competitivo imposto pela economia de mercado sem deixar de lado seus princípios norteadores?

Para sobreviver em uma economia de mercado, as OCPA devem buscar formas de manter-se competitivas? As OCPA devem recusar a utilização de tecnologias físicas sofisticadas? O grande desafio dessas iniciativas em termos de seu funcionamento se encontra nos riscos de instrumentalização das práticas e estruturas de gestão. Há uma tendência conceitual de considerar que o modelo de referência do modo associativo seja o mesmo que o do funcionamento de uma empresa privada ou de um serviço público. Essa concepção argumenta que não há como evitar a profissionalização da gestão dos empreendimentos para acompanhar certo nível de crescimento, o que implicaria a submissão da dimensão de projeto associativo (autônomo e espontâneo) aos imperativos funcionais (uma lógica instrumental), fundada em um modo formal de gestão na busca de resultados passíveis de quantificação (FRANÇA FILHO e LAVILLE, 2004). 
Robert Castel (1998) identifica modos de "quase-assistência ou de quase voluntariado" nessas iniciativas. Por isso, segundo o autor, muito poucas realizações dessa natureza são inovadoras e portadoras de futuro. Sua opinião é a de que, efetivamente, podem existir experiências que tentem mobilizar recursos monetários e não monetários, articular a esfera pública e a privada, os investimentos pessoais e as regulações gerais. Contudo, são pouco visíveis socialmente e não ultrapassam o estágio da experimentação. Salerno (2002) apresenta o mesmo ponto de vista, uma vez que não vê as organizações autogestionárias como uma saída para a economia, apenas as reconhece como uma saída eventual para as pessoas envolvidas. Há um questionamento em função do risco da falta de sustentação dessas unidades econômicas (LIMA, 2007).

Para os críticos das OCPA, essa forma de empreendimento não faz sentido, uma vez que se trata de tentar reunir elementos que se repelem e se opõem. No mundo da economia capitalista não haveria lugar para o trabalho e a produção associados, uma vez que esses espaços são regidos por outros fins, outras lógicas e outras práticas. Como as OCPA não constituem um modelo alternativo de organização social ao sistema de capital, mas uma forma alternativa de organização e gestão, sob o capitalismo, haveria uma impossibilidade de se construir tal projeto. Tal argumento se sustenta em uma condição concreta de que qualquer projeto amplo e abrangente de transformação das relações sociais de produção é inseparável da crítica econômica.

Os empreendimentos de autogestão no nível das unidades produtivas são considerados utópicos e de difícil sustentação, pois ao serem guiados por uma lógica não capitalista são incapazes de participar da dinâmica do mercado em condições de igualdade com as organizações típicas do sistema de capital. Ao se submeter às regras do mercado capitalista, buscando a inserção de seus partícipes no sistema de produção/consumo vigente, os elementos anticapitalistas diluem-se na competição típica das unidades de produção que precisam disputar mercados para a comercialização de seus produtos. 0 resultado é o retorno da reificação do trabalho e do fetichismo da mercadoria. Em outras palavras, a OCPA estaria confinada às suas próprias paredes, pois dadas as condições atuais de concentração e centralização do capital, seria condenada ao gueto das áreas de ação que o capital oligopolista ainda não tenha atingido ou pelas quais não mais se interesse. As condições de concorrência com empresas capitalistas estariam determinadas pela capacidade nitidamente superior destas de reproduzir de forma ampliada o capital, em virtude justamente do processo de exploração do trabalho excedente, afora suas condições privilegiadas de disputa, que são oriundas dos mecanismos de formação de monopólios (CRUZ, 2005).

As críticas, fundamentalmente corretas, precisam considerar, igualmente, as formas históricas de resistência, os enfrentamentos políticos, os tensionamentos no campo da produção social, enfim, as contradições inerentes ao modo de produção capitalista. É objetivamente verificável que a OCPA opere no terreno do sistema de capital, produzindo e vendendo mercadorias de forma competitiva, visando a acumular capital. Para seus críticos, a inviabilidade desse tipo de organização não se dá pelo fato dela ser o que é, mas pelo fato de que ela é o que não deveria ser. Os críticos a desejam não como uma forma elementar de resistência ao sistema de capital, mas como uma forma alternativa de organização desse sistema, com o objetivo de resolver os problemas estruturais do capitalismo, tais como desemprego, distribuição de renda, exclusão social etc. As OCPA deveriam ter, para esses críticos, a função de limpar os detritos econômicos e sociais que prejudicam a beleza aparente do sistema de capital. Entretanto, é exatamente pelo fato delas possuírem outra proposta que não disputam o terreno com o sistema de capital onde este é plenamente dominante. A OCPA se configura como resistência ao capitalismo em pequena escala. O fato de atuar na franja do sistema, na periferia do mercado capitalista, não significa que esse é seu único e viável lugar de existência. Significa que, diante da organização capitalista, esse é o lugar em que a OCPA se viabiliza como forma alternativa de organização e gestão.

Outra grande dificuldade das OCPA resulta da complexidade crescente da moderna divisão do trabalho, na qual grande parte das atividades especializadas é predeterminada, fazendo com que dificilmente se possa suprimir essa divisão completamente do processo econômico. Atualmente, o trabalho profissional envolve saberes cada vez mais qualificados e especializados, inserindo-se em uma "cultura tecnológica" e em uma complexa divisão macrossocial de tarefas. Isso sempre engendra um traço de alienação, que não se pode eliminar, inscrito de forma irreversível nas forças produtivas, pois a alienação do trabalho não se reduz à sua condição de mercadoria, nem seria revogada se esta pudesse ser abolida. A tendência à divisão técnica do trabalho, inclusive nas atividades produtivas autônomas, caracteriza uma autonomia na heteronomia.

Nas condições atuais, as OCPA experimentam uma dupla subsunção à economia capitalista: de um lado, estão sujeitas aos efeitos da lógica de acumulação e às regras de intercâmbio impostas ao conjunto dos agentes econômicos, de conteúdo eminentemente utilitário; de outro, como forma de responder à premissa de produtividade competitiva, estão compelidas a 
adotar a base técnica do capitalismo, os processos materiais de produção por ele introduzidos continuamente, configurando com isso uma subsunção inversa, de uma base sobre uma forma, similarmente ao caso da economia camponesa. Essas coerções, naturalmente, cerceiam a lógica econômica solidária, pois obrigam a conviver com tensionamentos e a conceder em seus princípios (GAIGER, 2005).

A autogestão no nível da unidade produtiva pode ser entendida como uma forma de organização das atividades sociais desenvolvidas mediante a cooperação de várias pessoas (atividades produtivas, serviços, atividade administrativa), na qual as decisões relativas à gerência são diretamente tomadas por quantos dela participam, com base na atribuição do poder decisório às coletividades definidas pelas estruturas específicas de atividade (GUILLERM e BOURDET, 1976). As características autogestionárias envolvem, em resumo, a gestão coletiva, o efetivo controle do processo de produção pelos trabalhadores e, de acordo com estudos conduzidos por Vargas de Faria (2003), a distribuição do resultado observando o trabalho aplicado na produção.

O que tem sido amplamente difundido sob o nome de organização autogerida deve ser tratado como organizações com características autogestionárias ou organizações de autogestão restrita ou parcial. No capitalismo, algumas organizações chamadas alternativas podem ter características autogestionárias ou características predominantemente autogestionárias. Ao estar inseridas na lógica do capital, as unidades produtivas autogeridas parciais atuam como unidades no interior do sistema de capital, ainda que como contradições em pequena escala (FARIA, 2006). Características estas que levam em consideração a proposta que está no âmago do conceito de autogestão social, mas que a adaptam a determinado contexto.

\section{CONSIDERAÇÕES FINAIS}

O objetivo deste ensaio foi reafirmar as distinções entre autogestão e práticas de gestão que se denominam autogestionárias. Não se trata de desvalorizar tais práticas, que constituem formas de resistência ao modo capitalista de produção, mas de afirmar que essas formas de gestão, conquanto possam ser consideradas uma negação singular do modo capitalista, não são sua síntese ou sua superação. Um modo de produção contém em si elementos de sua superação, mas tais elementos não são, eles mesmos, em suas particularidades, a própria superação de um modo de produção dominante por outro. O uso impreciso ou genérico de conceitos não apenas cria dificuldades de análise da realidade, mas é um obstáculo à sua transformação. Ainda que a realidade não seja transformada pela via da ideia ou do conceito, mas da prática que constitui suas relações sociais, a precisão conceitual é fundamental para que se estabeleça uma análise crítica da realidade e das necessárias intervenções que nela os movimentos sociais coletivos necessitam fazer. Não se pode atribuir a um processo, cujos desdobramentos históricos sequer se desenvolveram, a condição de ser ele mesmo já seu fim último.

Como foi explicitado no início deste ensaio, é conceitualmente adequado, oportuno, necessário e coerente tratar as OCPA como organizações com características autogestionárias e não como autogestão. A autogestão tem uma dimensão social e somente pode existir uma plena autogestão nas unidades produtivas quando o sistema social for autogestionário. Ignorar essa determinação implica atribuir a experiências singulares uma falsa condição de universalização. Embora fundamentos importantes do capitalismo já estivessem presentes no modo de produção feudal, foi histórica, social e economicamente necessário que o sistema de capital superasse o sistema feudal para se tornar um modo dominante de produção.

Às organizações com características autogestionárias corresponde a forma de gestão coletivista de trabalho, mas não propriamente uma autogestão. Sob o domínio do modo capitalista de produção, algumas organizações produtivas podem ter características predominantemente autogestionárias, constituindo um fator de contradição, porém, não de superação. Essas organizações produtivas foram denominadas e conceituadas aqui como OCPA. Entretanto, as OCPA, ao estarem inseridas na lógica do capital, atuam como unidades no sistema de capital, ainda que não pertençam diretamente a este, e constituem formas de resistência, em alternativas de práticas de produção da existência social e em contradições em escala reduzida do sistema de capital (FARIA, 2006). Não poderia ser diferente, pois se as OCPA não fossem parte do sistema de capital, não poderiam ser sua contradição, dado o princípio da unidade dos contrários.

A autogestão social só pode ser a síntese histórica desse processo. As características predominantemente autogestionárias das OCPA levam em consideração a proposta que está no âmago do conceito de autogestão social, mas que a adaptam a certo contexto concreta e historicamente determinado. A gestão democrática das OCPA, portanto, diz respeito a três aspectos 
fundamentais: (i) Participação na gestão, que pode ser analisada, como sugere Bernstein (1982, p. 53), a partir de três pontos fundamentais: (i) grau de controle que os trabalhadores exercem sobre qualquer decisão em particular: questões sobre as quais esse controle é exercido; nível organizacional no qual este controle é exercido; (ii) responsabilidade na gestão: pode ser analisada a partir da verificação de em que grau, sobre quais questões e em que nível organizacional esta ocorre, sendo esses os seus elementos constitutivos; (iii) acesso e domínio das informações relevantes para que o processo possa se efetivar: elemento essencial para que a participação seja qualificada, podendo ser analisada a partir da verificação da existência de condições que possibilitem aos trabalhadores tomarem posse das informações a partir das quais poderão basear sua decisão. Assim, é necessário que não apenas o acesso à informação seja disponibilizado, mas que essa informação esteja disponibilizada de modo a conceder condições mínimas para que os trabalhadores possam se apropriar dela (VARGAS DE FARIA, 2003).

Neste último caso, é conveniente chamar a atenção para o fato de que algumas atividades requererem conhecimentos especializados não é motivo para não democratizar a gestão. Em uma organização produtiva, especialmente mais complexa, é um equívoco supor que todos saibam tudo sobre todas as coisas, pois isso equivale a supor que todas as pessoas são constitutivamente iguais. O que se pode garantir em uma organização democrática é que as diferentes condições, habilidades e atividades não resultem em privilégios, hierarquias e em diferentes critérios de distribuição da riqueza coletivamente produzida. Também se deve garantir que as individualidades (e não o individualismo) permaneçam como direitos e não como padrões.

Já o processo de produção é, em termos sociais, a atividade voltada a produzir valores de uso que satisfaçam as necessidades humanas. Observando esse processo na esfera da unidade produtiva, pode-se identificar, de forma simplificada, três etapas que o compõe: (i) a concepção do produto; (ii) a forma de produção; e (iii) a destinação do produto. A análise acerca do controle do processo de produção pode dar-se levando em consideração a apropriação dos trabalhadores desses aspectos, tendo como pano de fundo as relações de propriedade real e legal inerentes a eles (FARIA, 1987).

Em relação à distribuição do resultado, entende-se que o valor produzido deve ser distribuído aos trabalhadores na proporção do tempo e da natureza do trabalho que realizam e da necessidade de reprodução de suas condições de vida, sem geração de valor excedente apropriado privadamente por outrem. O que se procura afirmar nesse caso é que a capacidade de trabalho na autogestão não se torna mercadoria força de trabalho, porém, deve-se considerar que o custo de produção e reprodução dessa capacidade de trabalho e das necessidades objetivas do trabalhador é determinado socialmente e não pelo coletivo de trabalhadores em determinada unidade de produção. Ainda sobre essa questão, o patrimônio (ou investimento social) aplicado na organização não pode valorizar de forma diferenciada entre os trabalhadores. O resultado de uma eventual ampliação de patrimônio pertence àquela sociedade, ou seja, torna-se coletivo (VARGAS DE FARIA, 2003).

Por fim, o objetivo deste ensaio não foi desqualificar os EES e seus correlatos, tampouco menosprezar essas iniciativas de oposição e resistência ao sistema de capital, mas estabelecer a necessária distinção conceitual entre esses empreendimentos e a autogestão, ou seja, a crítica desenvolvida neste ensaio se dirige aos equívocos conceituais, tanto os inseridos nas análises e propostas de economia solidária como os desenvolvidos a partir de suas experiências concretas. A existência de experiências caracteristicamente autogestionárias, singulares em unidades produtivas de EES, não autoriza a generalização conceitual que estabelece uma relação direta entre autogestão e EES. A imprecisão conceitual pode induzir uma falsa representação do real, seja esta devida à consideração do sensível imediato (a coisa em si) como sendo o próprio fenômeno, seja atribuindo à realidade qualidades que ela não possui. Não se trata, tal distinção, de enaltecer o "preciosismo acadêmico", mas de argumentar a favor do rigor de uma análise elaborada da realidade, fundamental não apenas para estabelecer a correta leitura do concreto, mas para igualmente permitir uma correta intervenção nele para fins de transformá-lo. 


\section{REFERÊNCIAS}

ANDRADA, C. F. O encontro da política com o trabalho: história e repercussões de experiências de autogestão das cooperadas da UNIVENS. Dissertação (Mestrado em Psicologia) - Universidade de São Paulo, São Paulo, 2005. Disponível em http://www.teses.usp. br/teses/disponiveis/47/47134/tde-22092005-123014/pt-br.php.

BERNSTEIN, P. Workplace democratization: its international dynamics. Kent: Kent University Press, 1976.

BERNSTEIN, P. Worker ownership and community development. [s.n.b], 1981.

BERNSTEIN, P. Necessary elements for effective worker participation in decision-making. In: LINDENFELD, F.; ROTHSCHILD WHITT, J. (Ed.). Workplace democracy and social change. Boston, MA: Porter Sargent, 1982. p. 51-81.

BOBBIO, N.; MATTEUCCI, N.; PASQUINO, G. Dicionário de política. Brasília, DF: Universidade de Brasília, 1986.

BUSNARDO, E. A. Autogestão em construção: uma cooperativa de construção civil do Rio de Janeiro. Cadernos de Psicologia Social do Trabalho, v. 9, n. 1, p. 53-71, 2006.

CANÇADO, A. C. Autogestão em cooperativas populares: os desafios da prática. 134 f. Dissertação (Mestrado em Administração) Universidade Federal da Bahia, Salvador, 2004.

CARLEIAL, L. M. F. Economia solidária: utopia transformadora ou política pública de controle social? Revista de Estudos de Direito Cooperativo e Cidadania, n. 2, p. 9-40, 2008.

CARVALHO, M.C. Autogestão, economia solidária e cooperativismo: uma análise da experiência política da Associação Nacional de Trabalhadores e Empresas de Autogestão. 119 f. Dissertação (Mestrado em Serviço Social) - Universidade Federal de Juiz de Fora, Juiz de Fora, 2012.

CASTEL, R. A metamorfose da questão social. Petrópolis, RJ: Vozes, 1998.

CHAVES, L. C. Laboratórios sociais de autogestão no Brasil e Argentina: cooperativas na produção e reprodução em cooperação. Tese (Doutorado em Sociologia Política) - Universidade Federal de Santa Catarina, Florianópolis, 2007.

CHRISTOFFOLI, P. I. O desenvolvimento de cooperativas de produção coletiva de trabalhadores rurais no capitalismo: limites e possibilidades. 323 f. Dissertação (Mestrado em Administração) Universidade Federal do Paraná, Curitiba, 2000.

CRUZ, A. O mar e a terra da economia solidária. Leituras Cotidianas, n. 181, 2005.

DEMO, P. Solidariedade como efeito de poder. Cortez: São Paulo, 2002.

DICKMANN, I.; DICKMANN, I. Cooperativa habitacional autogestionária: construindo alternativas coletivas. In: DICKMANN, I.; DICKMANN, I. (Org.). A questão da habitação popular. Curitiba: Base, 2015. p. 175-190.
DRU, J. O Estado, o plano e a república dos conselhos. Porto: Paisagem, 1975.

EID, F.; GALLO, A.; PIMENTEL, A. Desemprego, exclusão e desafios para o desenvolvimento da economia solidária no Brasil. Revista ABET, v. 1, n. 1, 2001.

FARIA, J. H. Relações de poder e formas de gestão. Curitiba: Criar, 1985.

FARIA, J. H. Comissões de fábrica: poder e trabalho nas unidades produtivas. Curitiba: Criar, 1987.

FARIA, J. H. Tecnologia e processo de trabalho. Curitiba: Editora UFPR, 1992.

FARIA, J. H. Economia política do poder: fundamentos. Curitiba: Criar, 2004. 3 v.

FARIA, J. H. Organizações solidárias, organizações coletivistas e autogestão: formas de resistência ou alternativas de trabalho? Curitiba: EPPEO, 2006. (Working Paper).

FARIA, J. H. Gestão participativa: relações de poder e de trabalho nas organizações. São Paulo: Atlas, 2009.

FARIA, J. H. Condições de uma gestão democrática do processo social de trabalho. In: ENANPAD, 39.; 2015, Belo Horizonte. Anais... Rio de Janeiro: ANPAD, 2015.

FARIA, M. S. Autogestão, cooperativa, economia solidária: avatares do trabalho e do capital. 399 f. Dissertação de Mestrado (Programa de Pós-Graduação em Sociologia Política) - Universidade Federal de Santa Catarina, Florianópolis, 2005.

FRANÇA FILHO, G. C.; LAVILLE, J.-L. A economia solidária: uma abordagem internacional. Porto Alegre: Ed. UFRGS, 2004.

GAIGER, L. I. Significados e tendências da economia solidária. In: CENTRAL ÚNICA DOS TRABALHADORES - CUT. Sindicalismo e economia solidária: reflexões sobre o projeto da CUT. São Paulo: CUT, 1999. p. 32-41.

GAIGER, L. I. Sentidos e experiência da economia solidária no Brasil. Porto Alegre: Ed. UFRGS, 2004.

GAIGER, L. I. A economia solidária diante do modo de produção capitalista. Leituras Cotidianas, n. 127. 2005.

GERMER, C. A economia solidária: uma crítica marxista. Revista de Estudos de Direito Cooperativo e Cidadania, n. 1, p. 51-73, 2007.

GODELIER, M. D'um mode de production à l'autre: théorie de la transition. Recherches Sociologiques, [s.n], p. 161-193, 1981.

GREENBERG, E. S. Workplace democracy: the political effects of participation. Ithaca, NY: Cornell University Press, 1986.

GUILLERM, A.; BOURDET, Y. Autogestão: uma mudança radical. Rio de Janeiro: Zahar, 1976.

HORVAT, B.; MARCOVIC, M.; SUPEK, R. Self-governing socialism: a reader. New York: International Arts and Science, 1975. 2 v.

LIMA, J. C. (Org.). Ligações perigosas: trabalho flexível e trabalho associado. São Paulo: Annablume, 2007. 
LINDENFELD, F.; ROTHSCHILD-WHITT, J. (Ed.). Workplace democracy and social change. Boston, MA: Porter Sargent, 1982.

MANCE, E. A. Redes de colaboração solidária: aspectos econômico-filosóficos (complexidade e libertação). Petrópolis, RJ: Vozes, 2002.

MANDEL, E. Control obrero, consejos obreros, autogestión. Mexico, DF: Era, 1974.

MARX, K. El capital: crítica de la economía política. Buenos Aires: Biblioteca Nueva, 1946.

MARX, K. Contribuição à crítica da economia política. São Paulo: Martins Fontes, 1977.

MENEZES, M. T. C. G. Economia solidária: elementos para uma crítica marxista. Rio de Janeiro: Gramma, 2007.

MÉSZÁROS, I. Para além do capital: rumo a uma teoria da transição. São Paulo: Boitempo, 2002.

MICHELS, T. Sociologia dos partidos políticos. Brasília: Editora UnB, 1982.

MONTUCLARD, M. Autogestão e dialética. Porto: Paisagem, 1975.

PANIAGO, M. C. S. Capital, controle social e participação autônoma dos trabalhadores no capitalismo em crise. Revista Katálysis, Florianópolis, v. 15, n. 1, p. 122-130, jan./jun. 2012

PEDRINI, D. M. Bruscor: uma experiência que aponta caminhos. In: Singer e Souza (2000).

PEDRINI, D. M. e SOUZA, André Ricardo (Orgs.). A Economia Solidária no Brasil: a autogestão como resposta ao desemprego. São Paulo: Contexto, 2000.
ROSANVALLON, Pierre. La autogestión. Madrid: Editorial Fundamentos, 1979.

SALERNO, M. S. Organizações de produção e do trabalho. São Paulo: ADS, 2002.

SINGER, P. Desafio à solidariedade. In: GUIMARÃES, G. Sindicalismo e cooperativismo. A economia solidária em debate. São Paulo: Unitrabalho, 1999. p. 63-76

SINGER, P. Introdução à economia solidária. São Paulo: Fundação Perseu Abramo, 2002.

SINGER, P. A economia solidária no Brasil. Autogestão como resposta à crise do emprego. São Paulo: Contexto, 2003.

SINGER, P. Em defesa dos direitos dos trabalhadores. 2004. Disponível em: <www.mte.gov.br/temas/economiasolidaria/textosdiscussões>. Acesso em: 11 set. 2017.

SINGER, P.; SOUZA, A. R. (Org.). A economia solidária no Brasil: a autogestão como resposta ao desemprego. São Paulo: Contexto, 2000.

TAUILLE, J. R.; RODRIGUES, H. Economia solidária e autogestão: a criação e recriação de trabalho e renda. Brasília, DF: Instituto de Pesquisa Econômica Aplicada, 2004.

TEIXEIRA, L. R. A ideologia política na economia solidária: uma análise de empreendimentos solidários em Salvador. São Paulo: Hucitec, 2010.

VARGAS DE FARIA, J. R. Organizações coletivistas de trabalho: autogestão nas unidades produtivas. 220 f. Dissertação (Mestrado em Administração) - Universidade Federal do Paraná, Curitiba, 2003.

VERARDO, L. Economia solidária e autogestão. Proposta, n. 98, p. 56-61, 2003.

José Henrique de Faria

Professor Titular Sênior da UFPR - Programa de Pós-Graduação em Administração - PPGADM; Pesquisador PQ/CNPq; Líder do Grupo de Pesquisa Economia Política do Poder e Estudos Organizacionais- EPPEO, UFPR/CNPq (desde 2002); Coordenador do Programa de Mestrado em Governança e Sustentabilidade do Instituto de Administração e Economia do Mercosul (ISAE-PR).E-mail: jhfaria@gmail.com 